\title{
KONFERENCIA BESZÁMOLÓ
}

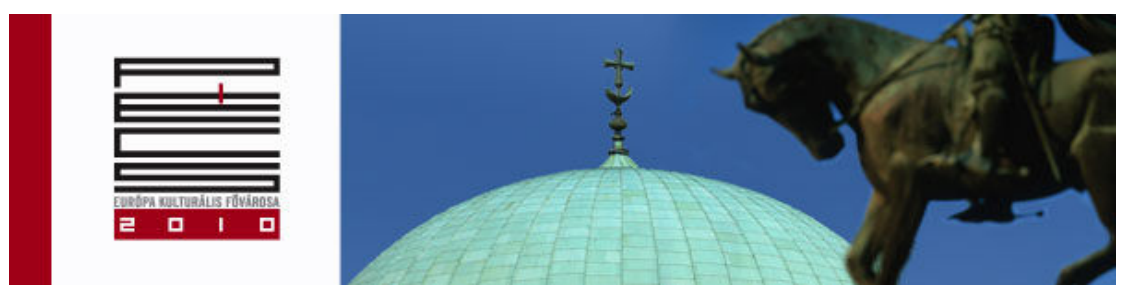

\section{DOKTORI ISKOLÁK „FÉLIDŐBEN” C. TALÁLKO- ZÓJA ÉS KONFERENCIÁJA}

\author{
(PTE KTK Regionális Politika és Gazdaságtan Doktori Iskola, \\ Pécs, 2010. október 8-9.) \\ BUDAY-SÁNTHA ATTILA
}

A Pécsi Tudományegyetem Közgazdaságtudományi Kar Regionális Politika és Gazdaságtan Doktori Iskolája a Pécs 2010 Európa Kulturális Fővárosa program keretében 2010. október 8-9-én rendezte meg a terület-, település-, vidék- és környezetfejlesztéssel foglalkozó doktori iskolák találkozóját és konferenciáját. A rendezvény részét képezte „A környezetgazdaságtant oktató felsőoktatási intézmények IV. éves Konferenciája” is.

A konferencia címe: „Félidőben”, arra utal, hogy az európai uniós tervezési időszak félidejéhez érkeztünk és jövőre meg kell kezdeni a következő tervezési időszakra (2014-2020) szóló felkészülést. Ehhez nekünk is tisztázni kell az egyes szakterületeken az eddig elért eredményeket, a tényleges helyzetet, és ebből kiindulva kell meghatározni a jövőbeni feladatokat. A doktori iskolák szakmai tanácskozása jelentősen hozzájárul ahhoz, hogy a kutatás és oktatás területén egy egységes szemlélet érvényesüljön.

A konferencia szekció ülésén a kormányzati képviselők (dr. Ángyán József államtitkár, dr. Szaló Péter helyettes államtitkár, dr. Nemes Csaba főosztályvezető) értékelték a jelenlegi helyzetet. Ezt követően került sor a már előre elkészített vitaanyagok alapján a doktori iskolák vitájára. Ezzel egyidejüleg a környezetvédelmi és területfejlesztési szekciók is megkezdték a munkájukat, amely a következő napon is folytatódott.

A következőkben a doktori találkozó vitaanyagait ismertetjük.

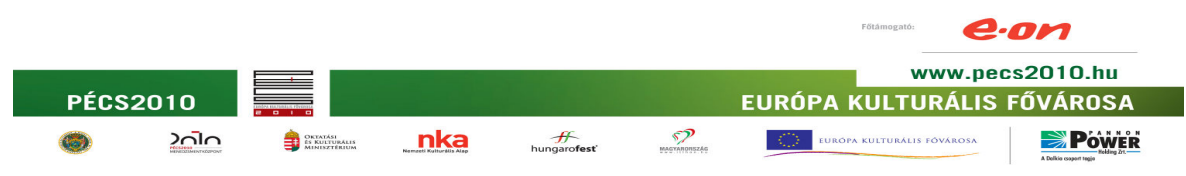




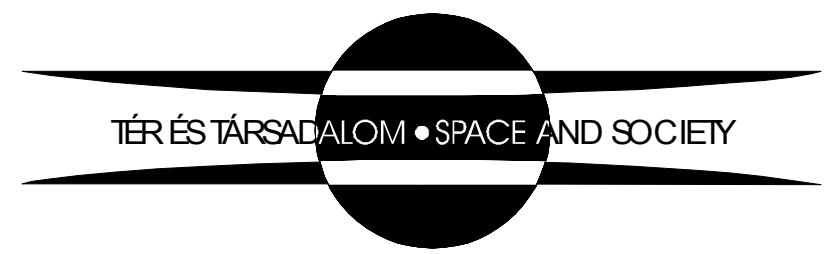

